\title{
Spatial Translation and Scaling Up of Low Impact Development Designs in an Urban Watershed
}

\author{
D. Di Vittorio and L. Ahiablame \\ Southern Illinois University Edwardsville, Edwardsville, Illinois.
}

Received 201412 12, accepted 201504 06, published 20150430.

\begin{abstract}
The downstream impacts of best management practices designed to manage stormwater at the source are not well documented. This study investigated two aspects of the hydrologic effects of low impact development (LID) practices at the watershed scale by examining the potential watershed benefits of the scaling up of LID designs, and evaluating the downstream effects of the spatial translation of LID designs within a watershed. PCSWMM was used to model long term runoff reduction with the implementation of LID practices in Deer Creek watershed, Missouri. The model was calibrated from 2003 to $2007\left(R^{2}=0.58\right.$ and NSE $\left.=0.57\right)$, and validated from 2008 to $2012\left(R^{2}=0.64\right.$ and NSE $\left.=0.65\right)$ for daily direct runoff. The calibrated model was used to simulate a baseline scenario for the study period, 2003 to 2012 (NSE $=0.61 ; R^{2}=0.63$ ), for comparison to LID scenarios. The baseline and all LID scenarios were developed based on the 2006 land cover map of the National Land Cover Database. A pre-development scenario was also developed with historical land cover to assess the ability of LID practices to restore pre-development hydrologic conditions.

Results showed an increased runoff reduction, from 3\% to $31 \%$, with increased implementation levels (from $25 \%$ to $100 \%$ ). As the spatial extent of LID practices increased, runoff reduction at the watershed outlet also increased, ranging from $3 \%$ to $19 \%$. When LID implementation was moved from one location to another in the watershed, simulation results revealed that an optimum location for placement of stormwater management practices was near the outlet for the study watershed, with a reduction in runoff ranging from $1 \%$ to $4 \%$. This study also showed that LID practices could be used to restore pre-development hydrologic conditions. The optimal location for LID practice implementation in this watershed appears to be near the outlet. Additional studies are however needed to better understand the optimum location for placement of stormwater management practices within a watershed.
\end{abstract}

Keywords: urbanization, runoff, urban expansion, modeling, PCSWMM.

\section{Introduction}

Urban growth generally results in the expansion of impervious surfaces in the form of roads, parking lots, sidewalks and rooftops. Increase in impervious surfaces has been identified as the primary contributor of hydrologic and water quality changes in urban watersheds (Shuster et al. 2005; O'Driscoll et al. 2010). Examples of the hydrologic implications of urbanization include, among others, increases of runoff rates and volumes, erosion of stream beds and banks, degradation of water quality in streams and shallow groundwater, degradation of aquatic habitats, reduction of infiltration, and decrease of aquifer recharge (Leopold 1968; Rose and Peters 2001; Tang et al. 2005).

During the early 1990s, low impact development (LID) strategies were developed for stormwater runoff management in Prince George's County, Maryland (USEPA 2000; Coffman 2002; HUD 2003). The LID approach seeks to maintain or restore predevelopment hydrologic conditions by minimizing the effects of impervious surfaces through the use of onsite management techniques (PGC 1999b; USEPA 2000; Coffman 2002). A large number of reported studies of both field monitoring and simulation modeling have shown the effectiveness of LID practices for managing stormwater quantity and quality (e.g. Davis 2005; Dietz 2007; Scholz and Grabowiecki 2007; Davis et al. 2009; Roy-Poirier et al. 2010; Berndtsson 2010; Rowe 2011; Ahiablame et al. 2012), resulting in a growing worldwide adoption of green infrastructure and LID practices (e.g. Dietz 2007; Zimmer et al. 2007; Lloyd 2001; Hunt and Lord 2006; Davis 2008; Fassman and Blackbourn 2010; Gregoire and Clausen 2011; Chaosakul et al. 2013).

Even though LID practices have been shown to effectively manage stormwater at the source, their performance at watershed scales is not well documented. Research is needed to evaluate the effectiveness of spatial translation and scaling up of LID technologies within a watershed. The objectives of this study

Vittorio, D.D. and L. Ahiablame. 2015. "Spatial Translation and Scaling Up of Low Impact Development Designs in an Urban Watershed." Journal of Water Management Modeling C388. doi: 10.14796/JWMM.C388.

(c) CHI 2015 www.chijournal.org ISSN: 2292-6062 
were (1) to determine the extent to which the scaling up of LID designs affects downstream runoff, and (2) to explore how the spatial translation of LID practices impacts runoff at the outlet of Deer Creek Watershed, Missouri. In this study, rain barrel, rain garden and porous pavement have been evaluated for their potential to reduce runoff at watershed scales.

\section{Methodology}

\subsection{Study Area}

Deer Creek Watershed (DCW) in St. Louis County, Missouri was selected as the study area (Figure 1). This watershed was chosen because of the high level of urbanization and the availability and number of streamflow gauges and historical data in it. DCW is approximately $93 \mathrm{~km}^{2}$, has a12-digit HUC (USGS and NRCS 2012), and is predominantly hydrologic soil group C. DCW covers 21 different municipalities (partly or fully) and has four land use types, based on the 2006 land cover data, classified as low intensity developed, high intensity developed, open water, and mixed forest (Figure 1 and Table 1). Pre-development land use conditions in DCW were characterized based on historical land cover data to allow comparison of model results between pre- and post-development conditions (Table 1). Detailed description of the pre- and post-development land uses is given in Section 2.2.

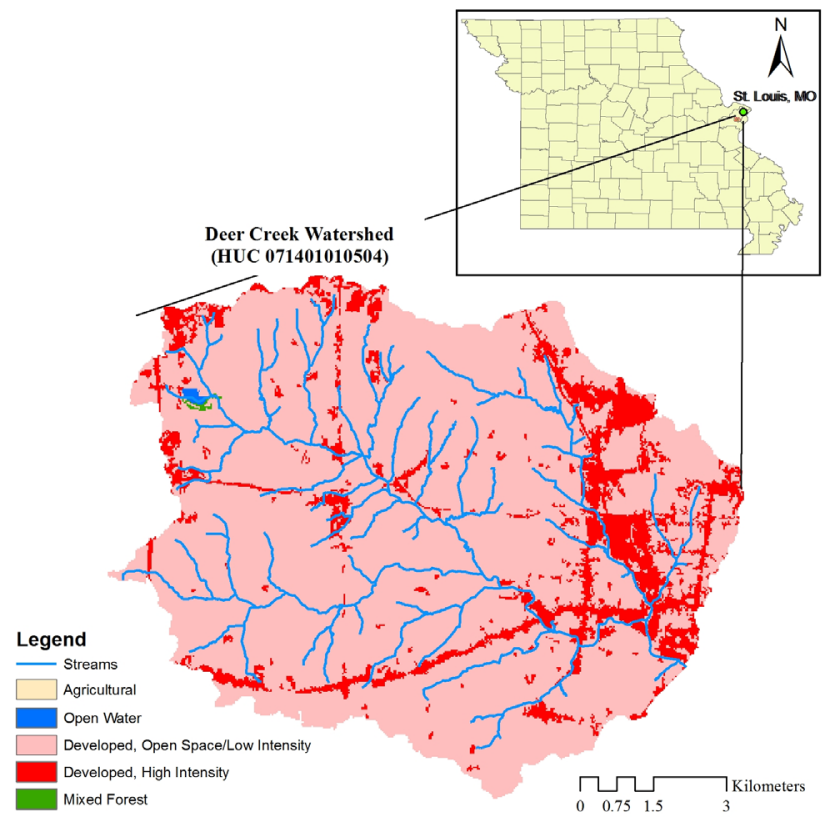

Figure 1 Deer Creek Watershed, St. Louis County, Missouri.

Table 1 Land use and land cover in Deer Creek Watershed.

\begin{tabular}{lcccc}
\hline \multicolumn{1}{c}{ Land Use Types } & \multicolumn{2}{c}{2006} & \multicolumn{2}{c}{1958} \\
& \% of Total & $\mathrm{km}^{2}$ & \% of Total & $\mathrm{km}^{2}$ \\
\hline Open Water & $0.1 \%$ & 0.1 & $0.1 \%$ & 0.1 \\
Developed, Open Space/Low Intensity & $86 \%$ & 80.3 & $37 \%$ & 34.5 \\
Developed, High Intensity & $13 \%$ & 12.8 & $8 \%$ & 7.5 \\
Mixed Forest & $0.1 \%$ & 0.1 & $1.4 \%$ & 1.3 \\
Agricultural & $0 \%$ & 0 & $53 \%$ & 49.8 \\
& $100 \%$ & 93.3 & $100 \%$ & 93.2 \\
\hline
\end{tabular}

\subsection{Data Used}

The major datasets used for the analysis consist of land cover maps, and soil, climate and streamflow data. Land use and land cover datasets used for the analysis consist of 2006 and 1958 land uses. The 2006 land cover data were obtained from the National Land Cover Database (NLCD). A pre-development condition in the watershed was defined using land cover data based on historic aerial photographs from 1958 which were mosaiced and georeferenced using ArcGIS tools. Polygons were delineated around areas of forested land (mixed forest) and agricultural and open space areas (Figure 2). The remainder of DCW not within these delineated polygons was assumed to be developed to the same extent as the 2006 land cover map (Figure 1 above).

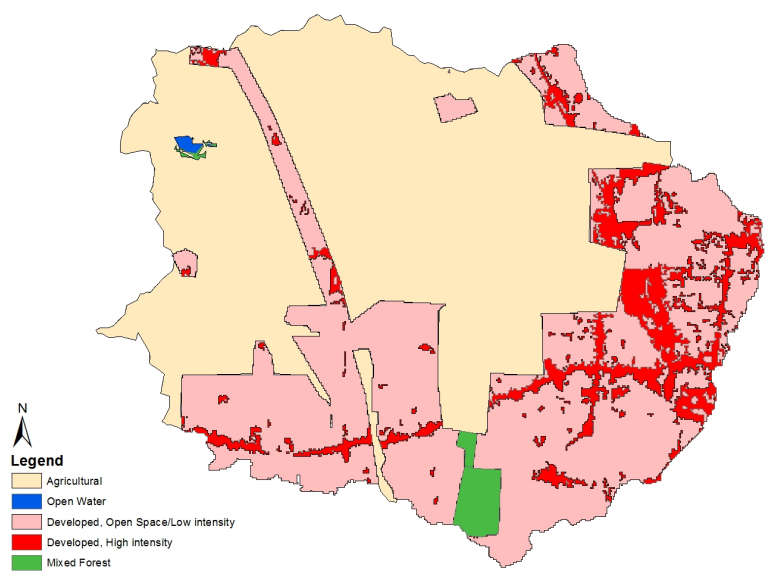

Figure 2 Historical land cover in Deer Creek Watershed, 1958.

The NLCD 2006 Developed land class has four levels of intensity (Open Space and Low, Medium and High Intensity), each with a different percentage of impervious area (Table 2; Fry et al. 2011). The midpoints of the ranges shown in Table 2 were used in the estimation of total impervious area (TIA). The Water and Wetlands land cover classes were assumed to have $0 \%$ imperviousness, and 1.9\% impervious was used for Mixed Forest (Choi et al. 2004). An area-weighted average based on land cover was used to estimate TIA for the watershed. Percent TIA values were then used to estimate a directly connected impervious areas (DCIA) percentage with Sutherland (2000) equations. Research has shown that DCIA is a better predictor of alternation of downstream ecosystems (Roy and Shuster 2009). The averages of watershed characteristics outlined in Sutherland (2000) were selected to represent DCW characteristics.

Table 2 Imperviousness of land cover types from the 2006 National Land Cover Database.

\begin{tabular}{|c|c|c|}
\hline Land Cover Code & Description & Percent Imperviousness \\
\hline 21 & Developed, Open Space & $0-20$ \\
\hline 22 & Developed, Low Intensity & $20-49$ \\
\hline 23 & Developed, Medium Intensity & $50-79$ \\
\hline 24 & Developed, High Intensity & $80-100$ \\
\hline
\end{tabular}


The U. S. Department of Agriculture (USDA) Soil Data Viewer 6.1 was used to access the Soil Survey Geographic database (SSURGO) to obtain the soil information of the watershed. The soil of the study area was classified as silt loam (NRCS 2014).

The rainfall data used for this study consisted of $1 \mathrm{~h}$ rainfall, obtained from the Lambert International Airport, St. Louis rain gauge ( $12 \mathrm{~km}$ from the watershed centroid) for the period 2003-01-01 to 2012-12-31. The dataset was downloaded from the National Climatic Data Center (NCDC). HydroDesktop, a web-service based hydrologic data acquisition and processing tool (Ames et al. 2012), was used to obtain North American Land Data Assimilation System (NLDAS) data which contain wind speed, evaporation, and minimum and maximum temperatures.

Streamflow data for the Maplewood, Missouri (USGS7010086) gauge station were obtained from the USGS National Water Information System for the period 2003-01-01 to 2012-12-31. This streamflow gauge station was used to delineate the study watershed, serving as the watershed outlet. Streamflow records were used to separate baseflow from direct runoff with the Web-based Hydrograph Analysis Tool (WHAT) (Lim et al. 2005). The direct runoff (DR) obtained from WHAT was used to calibrate and validate the model for scenario simulations. Detailed description of specific data compilation and processing is provided in Di Vittorio (2014).

\subsection{Model Calibration, Validation and Baseline}

The study period was 2003-01-01 to 2012-12-31. The model was calibrated for daily direct runoff (DR) with data of the first five years (2003-01-01 to 2007-12-31) and validated with data for the remaining five years (2008-01-01 to 2012-12-31). The simulated runoff was compared with observed runoff, derived with WHAT (Lim et al. 2005). The model was manually calibrated for daily runoff and two statistics, Nash-Sutcliffe efficiency (NSE) and the coefficient of determination $\left(R^{2}\right)$, were used to assess how well the simulated daily runoff fit observed daily DR. The calibration and validation exercise resulted in NSE $=0.57$ and $R^{2}=$ 0.58 . The validation period yielded similar results with NSE $=0.64$ and $R^{2}=0.67$. Runoff simulated for the entire study period (2003-01-01 to 2007-12-31) was used as baseline for comparison with the LID scenarios developed for the analysis. The baseline model, after calibration and validation, showed NSE $=0.61$ and $R^{2}=0.63$. These statistics were deemed reasonable for daily runoff simulations and for the objectives of the study (Moriasi et al. 2007).

\subsection{Simulation Scenario Development}

Arc Hydro tools were used to delineate the DCW in 117 subcatchments and PCSWMM was used to evaluate the long term effectiveness of three LID practices: rain barrel (RB), rain garden (RG), and porous pavement (PP). The three LID practices were modeled individually and in combination in the form of vertical layers (Rossman 2010) using LID editor algorithms and the Green-Ampt method for infiltration of the SWMM engine. A baseline and a pre-development land cover scenario were developed to assess the ability of LID scenarios to reduce runoff at the watershed outlet and to restore the pre-development hydrologic regime. The baseline and all LID scenarios were simulated using NLCD 2006 land cover. A detailed description of the assumptions and steps on LID design and representation in the model are provided in $\mathrm{Di}$ Vittorio (2014).

Rain barrels and rain gardens were implemented only in residential settings and received runoff from roof downspouts. The conceptual model simplified an average roof area into four equal sections, and each section was assumed to be DCIA and sending runoff to one downspout. For the purpose of LID simulation, an assumption was made that a home implementing rain barrels would have 3 downspouts ( $75 \%$ of the average roof area) routed to three rain barrels of approximately $280 \mathrm{~L}$ each on the property and a home implementing a rain garden would have one downspout (or $25 \%$ of the roof area) routed to a rain garden on the property. The model parameters used for modeling the two practices are shown in Tables 3 and 4.

Table 3 Input parameter values for rain barrel simulation.

\begin{tabular}{lcll}
\hline \multicolumn{1}{c}{ Layer Parameter (units) } & Value & & Source \\
\hline Storage Layer & & \\
Height (mm) & 914 & Assumption \\
Void Ratio (fraction) & 1 & (Void ratio of an open container) \\
Underdrain Layer & & \\
Drain Coefficient (mm/h) & 2.51936 & Rossman 2010 \\
Drain Exponent & 0.5 & Rossman 2010 \\
Drain Offset Height (mm) & 0 & Assumption \\
Drain Delay (h) & 24 & Walsh et al. 2013 \\
\hline
\end{tabular}

Table 4 Input parameter values for rain garden simulation.

\begin{tabular}{lcll}
\hline \multicolumn{1}{c}{ Layer Parameter (units) } & Value & & Source \\
\hline Surface Layer & & \\
Storage Depth (mm) & 152.4 & WDNR 2003 \\
Vegetative Cover (fraction) & 0.15 & James et al. 2010 \\
Surface Roughness (n) & 0.2 & James et al. 2010 \\
Surface Slope (\%) & 1.0 & James et al. 2010 \\
Soil Layer & & \\
Thickness (mm) & 177.8 & WDNR 2003 \\
Porosity (volume fraction) & 0.501 & Rossman 2010 \\
Field Capacity (volume fraction) & 0.284 & Rossman 2010 \\
Wilting Point (volume fraction) & 0.135 & Rossman 2010 \\
Soil Conductivity (mm/h) & 12.7 & Assumed amended soil with 0.5 in./h rate \\
Conductivity Slope & 7.7225 & Huber and Dickinson 1988 \\
Suction Head (mm) & 304.8 & NRCS 2014 \\
Storage Layer & & \\
Height (mm) & 0 & Rossman 2010 \\
Void Ratio (fraction) & 1 & (Void ratio of an open container) \\
Filtration Rate (mm/h) & 4.326 & NRCS 2014 \\
Clogging Factor & - & \\
Underdrain & & \\
Drain Coefficient & 0 & Rossman 2010 \\
Drain Exponent & - & \\
Drain Offset Height & - & \\
Drain Delay & & \\
\hline
\end{tabular}


Porous pavement is not well suited for application to high traffic roadways and therefore this practice was only applied to residential streets (no highways or state roads). The simulated porous pavement did not include receiving runoff from other impervious surfaces, only direct interception of rainfall. In practice, local roads would receive runon from adjacent areas (e.g. driveways, properties sloped towards the road); however, this was not accounted for in this study due to the complexity of detailed routing in such a large size study area. The model parameters used for modeling this practice are shown in Table 5.

Table 5 Input parameter values for porous pavement simulation.

\begin{tabular}{lcll}
\hline \multicolumn{1}{c}{ Layer Parameter (units) } & Value & \multicolumn{1}{c}{ Source } \\
\hline Surface Layer & & \\
Storage Depth (mm) & - & \\
Vegetative Cover Fraction (fraction) & - & \\
Surface Roughness (n) & 0.1 & Rossman 2010 \\
Surface Slope (\%) & 1.0 & MWS 2012 \\
Swale Side Slope (rise/run) & - & \\
Pavement Layer & & \\
Thickness (mm) & 125 & MWS 2012 \\
Void Ratio (fraction) & 0.15 & Rossman 2010 \\
Impervious Surface Fraction (fraction) & 0.0 & N/A continuous surface PP system \\
Permeability (mm/h) & 2540.0 & Rossman 2010 \\
Clogging Factor & 590.0 & Rossman 2010 \\
Storage Layer & & \\
Height (mm) & 300.0 & WVDEP 2012 \\
Void Ratio (fraction) & 0.75 & Rossman 2010 \\
Filtration Rate (mm/h) & 4.32 & NRCS 2014 \\
Clogging Factor & 0 & Assumption \\
Underdrain & & \\
Drain Coefficient (mm/h) & 0.2 & Assumption \\
Drain Exponent & 0.5 & James et al. 2010 \\
Drain Offset Height (mm) & 100.0 & WVDEP 2012 \\
Drain Delay & - & \\
\hline
\end{tabular}

\subsection{LID Simulation Scenarios}

The calibrated and validated model (i.e. the baseline model) was modified to create what if scenarios by adding model parameters that represent LID practices as described in Section 2.4.

To investigate the scaling effects of the three LID practices (rain barrels, rain gardens and porous pavement) in reducing runoff, two approaches for scaling up LID implementation levels were used. The first approach incrementally and concurrently expands the implementation of LID practices in all 117 DCW subwatersheds at $25 \%, 50 \%, 75 \%$ and $100 \%$ implementation levels (Table 6). This approach is conventionally named incremental scaling. The second approach, or spatial scaling, combined all the three practices implemented at $50 \%$ and the DCW was divided into six subwatershed groups (G1-G6). The subwatersheds were manually grouped to ensure that all subwatersheds within a group were upstream of the outlet of the group, and the areas of the groups were relatively similar (Figure 3; Tables 7, 8 and 9). Six scenarios (all three practices combined at $50 \%$ implementation level) were then defined to consecutively and additively simulate one at a time the implementation of LID practices in the subwatershed groups, spatially increasing the overall scale of LID practices (Figure 3).

Table 6 Simulation scenarios for scaling LID implementation.

\begin{tabular}{lcccc}
\hline \multirow{1}{*}{ LID Practice } & \multicolumn{4}{c}{ Implementation Level } \\
& $25 \%$ & $50 \%$ & $75 \%$ & $100 \%$ \\
\hline Rain Barrel & RB25 & RB50 & RB75 & RB100 \\
Rain Garden & RG25 & RG50 & RG75 & RG100 \\
Porous Pavement & PP25 & PP50 & PP75 & PP100 \\
\hline
\end{tabular}

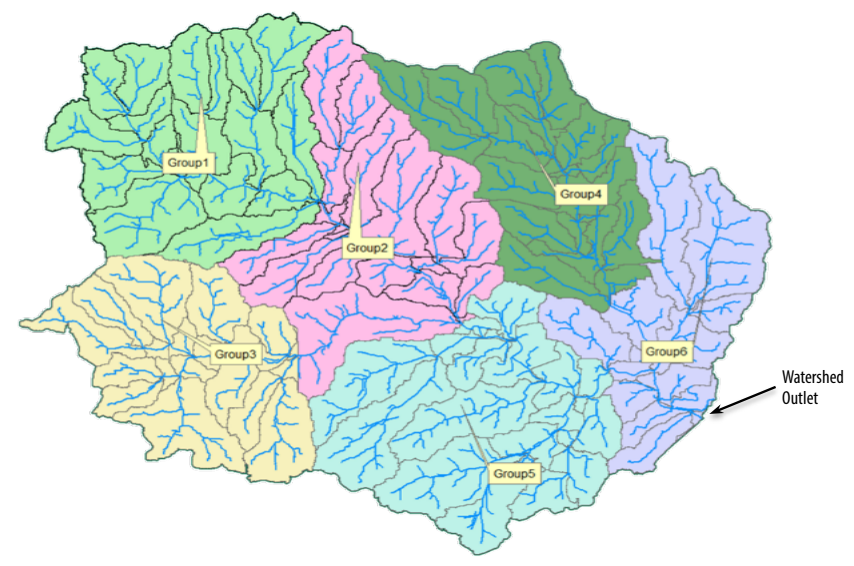

Figure 3 Subwatershed groups for spatial scaling in the watershed.

Table 7 Subwatershed group areas for spatial scaling in the study watershed.

\begin{tabular}{|c|c|c|c|}
\hline Group & Area $\left(\mathrm{km}^{2}\right)$ & Subwatershed Count & $\mathrm{DCIA}\left(\mathrm{km}^{2}\right)$ \\
\hline $\mathrm{G1}$ & 17.7 & 20 & 4.6 \\
\hline $\mathrm{G} 2$ & 17 & 22 & 4.0 \\
\hline G3 & 14 & 20 & 3.2 \\
\hline G4 & 13.9 & 20 & 4.3 \\
\hline G5 & 18.4 & 21 & 4.7 \\
\hline G6 & 12.3 & 14 & 4.6 \\
\hline Total & 93.2 & 117 & 25.4 \\
\hline
\end{tabular}

Table 8 Normalized area treated with the number of rain barrel (RB), rain garden (RG), and porous pavement (PP) areas implemented.

\begin{tabular}{lcccccc}
\hline \multirow{2}{*}{ Group } & $\begin{array}{c}\text { Area treated } \\
\text { /DCIA }\end{array}$ & $\begin{array}{c}\text { Area treated } \\
\text { /DCIA }\end{array}$ & $\begin{array}{c}\text { Area treated } \\
\text { /DCIA }\end{array}$ & $\begin{array}{c}\mathrm{RB} \\
\text { (Count) }\end{array}$ & $\begin{array}{c}\mathrm{RG} \\
\text { (Count) }\end{array}$ & $\begin{array}{c}\mathrm{PP} \\
\left(\times 10^{5} \mathrm{~m}^{2}\right)\end{array}$ \\
\hline $\mathrm{G1}$ & 0.091 & 0.031 & 0.091 & 1805 & 5415 & 5.4 \\
$\mathrm{G} 2$ & 0.091 & 0.030 & 0.092 & 1359 & 4077 & 4.2 \\
G3 & 0.091 & 0.030 & 0.092 & 1981 & 5943 & 5.3 \\
G4 & 0.091 & 0.031 & 0.091 & 2289 & 6867 & 6.1 \\
G5 & 0.091 & 0.031 & 0.092 & 5048 & 15144 & 8.5 \\
G6 & 0.091 & 0.030 & 0.092 & 3359 & 10077 & 5.7 \\
\hline
\end{tabular}


Table 9 Percent of land use types in the study watershed and subwatershed groups based on the 2006 National Land Cover Database.

\begin{tabular}{lccccccc}
\hline \multicolumn{1}{c}{ Group } & \% of Total & G1 & G2 & G3 & G4 & G5 & G6 \\
\hline $\begin{array}{l}\text { Open Water } \\
\text { Developed, Open }\end{array}$ & 0.1 & 0.1 & 0.0 & 0.0 & 0.0 & 0.0 & 0.0 \\
$\begin{array}{l}\text { Space/Low Intensity } \\
\text { Developed, High }\end{array}$ & 86 & 16.4 & 17.0 & 14.1 & 11.9 & 17.6 & 9.1 \\
$\begin{array}{l}\text { Intensity } \\
\text { Mixed Forest }\end{array}$ & 13.9 & 2.4 & 1.2 & 0.9 & 3.0 & 2.1 & 4.2 \\
Agricultural & 0.1 & 0.1 & 0 & 0 & 0 & 0 & 0 \\
\hline
\end{tabular}

The implementations of LID practices in the subwatershed groups were referred to as Case 1 through Case 6 (C1-C6), with C1 corresponding LID implementation in only one subwatershed group and $\mathrm{C} 6$ being the case where LID practices were implemented in all subwatershed groups. The $50 \%$ implementation level is representative of both homeowner implementation (for rain barrel and rain garden) and municipality implementation of LID practices.

To gain an understanding of how varying the location of LID implementation within the watershed would impact the benefits observed at the outlet, the same six subwatershed groups were used. The implementation level of LID practices were normalized with DCIA and area treated using $\mathrm{G} 6$ as the smallest group (Di Vittorio 2014), so that both LID implementation and scenario results are comparable from one group to another. Similarly to the incremental scaling cases, implementations of LID practices in the individual subwatershed groups were also described in six cases, where each case corresponds to LID implementation in one and only one subwatershed group at a time.

\section{Results and Discussions}

\subsection{Baseline and Pre-Development Scenarios}

The calibrated and validated baseline model was used to simulate average annual runoff (AAR) for NLCD 2006 land cover (i.e. the baseline) and 1958 historical land cover (pre-development) for the entire study period (2003-01-01 to 2012-12-31). The baseline and pre-development scenarios showed simulated AAR of $247 \mathrm{~mm}$ and $161 \mathrm{~mm}$ respectively (Table 10). Runoff increased approximately $53 \%$ from the pre-development condition to the baseline condition. This result illustrates, as other studies have discussed, the impacts of land cover change and imperviousness in watershed hydrology (e.g. PGC 1999a; Sutherland 2000; Lee and Heaney 2003). Over the study period (2003-01-01 to 2012-12-31), average annual rainfall was $929 \mathrm{~mm}$. Average annual streamflow at the watershed outlet (Maplewood gauge station) was $316 \mathrm{~mm}$ and observed annual runoff averaged $\sim 250 \mathrm{~mm}$ (i.e. $27 \%$ of streamflow at the watershed outlet).
Table 10 Simulated average annual runoff for the baseline and pre-development scenarios in Deer Creek Watershed.

\begin{tabular}{lccc}
\hline \multicolumn{1}{c}{ Scenario } & $\operatorname{AAR}^{*}\left(\mathrm{~m}^{3} / \mathrm{y}\right)$ & $\operatorname{AAR}^{*}(\mathrm{~mm} / \mathrm{y})$ & \% Change \\
\hline Baseline & 23000000 & 247 & - \\
Historic & 14970000 & 161 & 53 \\
\hline${ }^{*}$ AAR is average annual runoff simulated in the watershed &
\end{tabular}

\subsection{Spatial Scaling of LID Implementation Levels}

Each of the three LID practices modeled in the incremental scaling scenarios (i.e. 25\%, 50\%, 75\% and 100\% implementation levels) showed a decrease in AAR, compared to the baseline scenario, as implementation level increased (Figure 4).

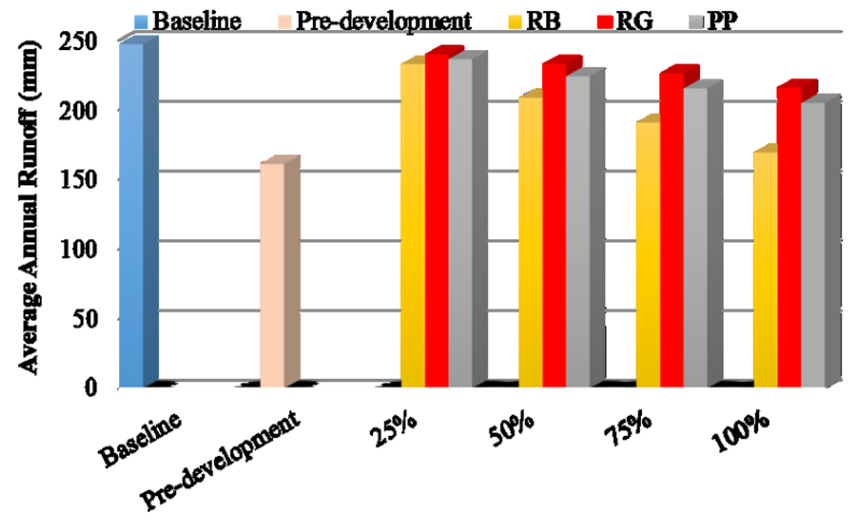

Figure 4 Comparison of average annual runoff between the base case, pre-development case and incremental scaling of LID implementation levels in Deer Creek Watershed.

The RB simulations achieved the lowest levels for all four implementation levels with AAR ranging from $233 \mathrm{~mm}$ for RB 25\% to $169 \mathrm{~mm}$ for RB $100 \%$ (Figure 4). Following the same trend, RG and PP scenarios showed AAR reduction from $240 \mathrm{~mm}$ to $216 \mathrm{~mm}$ and 236 to $205 \mathrm{~mm}$, respectively, from $25 \%$ to $100 \%$ implementation (Figure 4). None of the scenarios were able to fully recapture the pre-development AAR (Figure 4; Table 6). However, RB implemented at $100 \%$ level in the watershed came close, recovering $90 \%$ of the runoff increase between pre-development and baseline scenarios (Figure 4; Table 6). Runoff reduction varies between practices due to the differences in storage created by individual practice and routing of rainfall (by PP) or roof runoff (by RB and RG). The RB scenarios have a larger area draining into them (75\% of the average roof area) and PP scenarios have a larger surface area intercepting rainfall, compared to $\mathrm{RG}$ receiving rainfall from only $25 \%$ of the roof area.

The incremental scaling of LID practices resulted in reductions of $5.6 \%$ to $31 \%$ for RB, $2.8 \%$ to $12.5 \%$ for RG and $4.2 \%$ to $17 \%$ for PP from the base scenario (Figure 5). These results are comparable to those of a similar study conducted by Walsh et al. (2013), in which the authors modeled incremental implementation of various rainwater harvesting cases in the Chollas Creek 
Watershed, California. For similar sized of rain barrels (227 L in their study versus $280 \mathrm{~L}$ in this study), the authors showed AAR reductions from $3 \%$ to $14 \%$. Other researchers also reported a similar trend of increasing runoff reduction with increasing incremental LID implementation levels (Ahiablame et al. 2013).

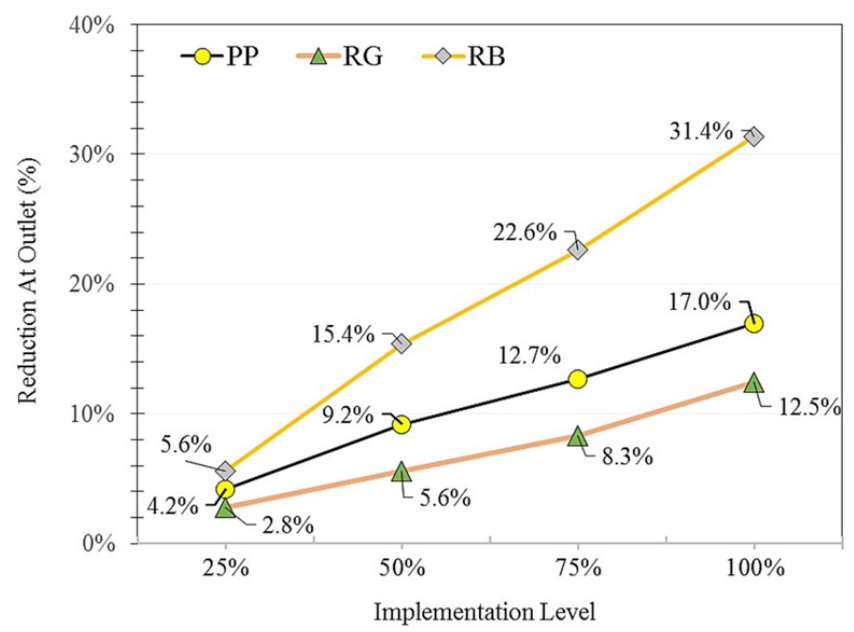

Figure 5 Percentage reduction in average annual runoff for incremental scaling of LID implementation levels in Deer Creek Watershed.

When the three LID practices (RB, RG and PP) were combined and implemented at $50 \%$ in the watershed, the simulation results showed that increase in percent reduction in AAR is directly driven by increased spatial coverage of LID practices (i.e. the area treated). Reduction in AAR for $\mathrm{C} 1$ through $\mathrm{C} 6$ resulted in $3 \%$, $9 \%, 10 \%, 13 \%, 16 \%$ and 20\%, respectively (Table 6; Figures 3 and 6). This was expected as when LID implementation level increases to treat larger areas, greater impact (i.e. runoff reduction) will likely be observed at the watershed outlet.

Case 6 has all three practices implemented at 50\% in all subwatershed groups (i.e. throughout the entire watershed), and a reduction of $19.5 \%$ in AAR (Figure 6). The implementation of LID practices in $\mathrm{C} 6$ can be conceptualized by the following expression: $\mathrm{C} 6=\mathrm{RB} 50$ + RG50 + PP50, where RB50, RG50, PP50 are the scenarios defined in Table 6. However, C6 showed a lower AAR reduction compared to the individual results of the three practices at $50 \%$ implementation level when summed up together (i.e. $15 \%$ $+6 \%+9 \%$ in Figure 5). This sum equals $30 \%$ not $20 \%$ in C6. This difference could be explained by the fact that in this study the three LID practices were not implemented as a treatment train as they treat entirely separate areas (RB for $75 \%$ of rooftop, RG for $25 \%$ of rooftop, PP for road surfaces), which could limit their interactions. Ahiablame et al. (2013) also found similar performance of LID practices with the combination of two practices (RB and PP). Given the scope of this study, further analysis is needed to fully explore the large difference between the cumulative effect of individual LID implementation (RB50, RG50, PP50) and the effect of the implementation of combined LID practices (RB50 + RG50 + PP50).

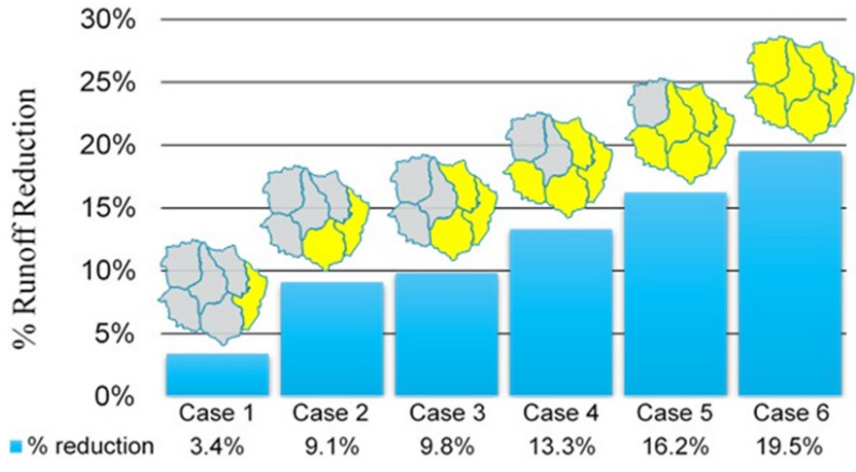

Figure 6 Spatial scaling of combined rain barrel, rain garden and porous pavement, each at $50 \%$ implementation level, within Deer Creek Watershed.

\subsection{Spatial Variability of LID Implementation}

The six scenario runs to examine the effect of spatial variability of the performance of LID practices at the DCW outlet showed differences in percentage runoff reduction among the cases (Figure 7). The percentage reductions for each case were found to be $3.1 \%, 2.8 \%, 2.5 \%, 0.6 \%, 3.7 \%$, and $3.4 \%$ (respectively C1 through C6; Figure 7). It appears that downstream scenarios seem to perform better than upstream scenarios. The simulations also suggest that a relationship between to the performance of LID practices and the location of their implementation may exist (Figure 7). It was expected that LID practices implemented downstream of the watershed will likely perform better than those implemented upstream. However, there was no detectable trend for the effectiveness of LID practices with respect to the implementation location (e.g. C4 and the other cases; C5 and C6) in this study and the simulation results were not conclusive.

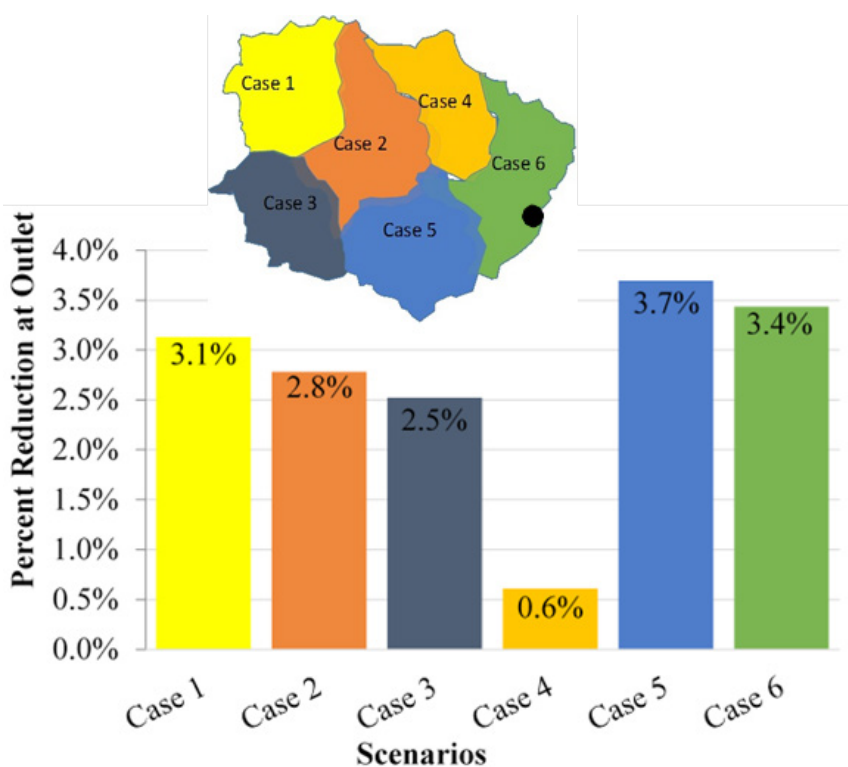

Figure 7 Performance of LID practices with respect to their implementation location in Deer Creek Watershed. 
This study is a preliminary exploration of examining spatial relationships of LID practices' effectiveness and their implementation locations within a watershed (i.e. the optimal location for LID implementation within a watershed to obtain maximum LID effectiveness). Even though the simulation results were inconclusive, this study indicates that the optimal location for LID implementation would be near this watershed's outlet, in G5 or G6 (C5 and C6). This study calls for further simulations and analyses to investigate the relationship between the LID implementation locations within a watershed and their effectiveness at the watershed outlet. There are many factors (e.g. soil type and slope) that control a watershed's hydrologic response. These factors were not explicitly taken into consideration in this study because soil types were relatively uniformly distributed in the DCW, which has mild slopes throughout, leading to the assumption that their respective impacts on the results would not be considerable (Di Vittorio 2014).

\section{Conclusions}

This study investigated the ability of LID practices to reduce average annual runoff (AAR) at the watershed scale. The analysis for the incremental scaling showed that the percentage reduction varied between practices at the same implementation levels. Ranges for AAR percentage reduction varied from $2.8 \%$ to $5.6 \%$ at the $25 \%$ implementation level and from $12.5 \%$ to $31.4 \%$ at the $100 \%$ implementation level for the individually LID practices simulated (RB, RG and PP). Rain gardens showed the lowest overall reductions in AAR, ranging from $2.8 \%$ for the $25 \%$ implementation level to $12.5 \%$ for the $100 \%$ implementation level. Porous pavement showed percentage reductions in AAR ranging from $4.2 \%$ to $17.0 \%$ for the $25 \%$ and $100 \%$ implementation levels. Rain barrel simulations provided the largest percentage reduction at all implementation levels ( $5.6 \%$ to $31.4 \%$, corresponding to $25 \%$ and $100 \%$ implementation levels).

For the spatial scaling, the percentage reduction in AAR also increased from $3 \%$ to $20 \%$ as the extent of LID practice implementation increased throughout the study watershed. This illustrates the importance of watershed level integrated stormwater management planning to achieve long term runoff reductions, highlighting the need for coordination and public participation to restore a watershed to the pre-development hydrologic regime.

The effectiveness of the practices modeled at different scales in this study can be important to planners and other stakeholders working to develop an integrated stormwater management plan at the watershed level, given insight into the relative benefits of one practice over another. Furthermore, this study showed that LID practice implementation is a viable means of regaining pre-development hydrologic conditions with the RB $100 \%$ scenario recapturing $90 \%$ of increased runoff in the watershed between 1958 (pre-development condition) and 2006 (baseline scenario). This research also shows there may be an optimal combination of LID practices to achieve maximum performance at the watershed outlet, suggesting the need for the use of optimization techniques in LID planning and implementation processes.

Results for the LID practice placement variability in the study watershed showed greater reduction when practices were implemented near the outlet. These results should be used with caution as there are many factors, such as soil type, slope, development type (i.e. low intensity versus high intensity), and other watershed characteristics, which drive a watershed's hydrologic response. These factors were not taken into account in this study. Understanding the relationship between placement of LID practices and their effectiveness within a watershed would aid planners, watershed managers and stakeholders in making informed decisions surrounding the placement of stormwater management practices. The analysis also suggests that the assessment of an optimum location for maximum LID effectiveness within a watershed should be conducted with more rigorous approaches.

\section{References}

Ahiablame, L. M., B. A. Engel and I. Chaubey. 2012. “Effectiveness of Low Impact Development Practices: Literature Review and Suggestions for Future Research." Water, Air, \& Soil Pollution 223 (7): 4253-73.

Ahiablame, L. M., B. A. Engel and I. Chaubey. 2013. “Effectiveness of Low Impact Development Practices in Two Urbanized Watersheds: Retrofitting with Rain Barrel/Cistern and Porous Pavement." Journal of Environmental Management 119:151-61.

Ames, D., J. Horsburgh, Y. Cao, J. Kadlec, T. Whiteaker and D. Valentine. 2012. "HydroDesktop: Web Services-Based Software for Hydrologic Data Discovery, Download, Visualization and Analysis." Environmental Modeling \& Software 37:146-56.

Berndtsson, J. C. 2010. “Green Roof Performance Towards Management of Runoff Water Quantity and Quality: A Review." Ecological Engineering 36:351-60.

Chaosakul, T., T. Koottatep and K. Irvine. 2013. "Low Impact Development Modeling to Assess Localized Flood Reduction in Thailand." Journal of Water Management Modeling R246-18. doi: 10.14796/JWMM.R246-18.

Choi, J.-Y., T. Zhai and B. A. Engel. 2004. How_Imperv. Retrieved October 7, 2013, from LTHIA, https://engineering.purdue.edu/ mapserve/LTHIAWD/wi/htmls/how_imperv.html.

Coffman, L. S. 2002. “Low Impact Development: An Alternative Stormwater Management Technology." In Handbook of Water Sensitive Planning and Design, ed. R. L. France, 97-124. Washington, DC: Lewis.

Davis, A. L., 2005. “Green Engineering Principles Promote Low Impact Development." Environmental Science \& Technology 39:338A-344A. 
Davis, A. P. 2008. "Field Performance of Bioretention: Hydrology Impacts." Journal of Hydrologic Engineering 13:90-5.

Davis, A. P., W. F. Hunt, R. G. Traver and M. Clar. 2009. “Bioretention Technology: Overview of Current Practice and Future Needs." Journal of Environmental Engineering 135:109-17.

Dietz, M. E. 2007. “Low Impact Development Practices: A Review of Current Research and Recommendations for Future Directions." Water, Air, \& Soil Pollution 186:351-63.

Di Vittorio, D. 2014. Spatial Translation and Scaling Up of LID Practices in Deer Creek Watershed in East Missouri. Edwardsville, IL: Southern Illinois University Edwardsville. M.S. Thesis.

Fassman, E. A. and S. Blackbourn. 2010. “Urban Runoff Mitigation by a Permeable Pavement System over Impermeable Soils." Journal of Hydrologic Engineering 15:475-85.

Fry, J., G. Xian, S. Jin, J. Dewitz, C. Homer, L. Yang, C. Barnes, N. Herold and J. Wickham. 2011. "Completion of the $2006 \mathrm{Na}$ tional Land Cover Database for the Conterminous United States." Photogrammetric Engineering and Remote Sensing 77 (9): 858-64.

Gregoire, B. G. and J. C. Clausen. 2011. "Effect of a Modular Extensive Green Roof on Stormwater Runoff and Water Quality." Ecological Engineering 37:963-9.

Huber, W. C., and R. E. Dickinson. 1988. Storm Water Management Model, Version 4: User's Manual. Athens, GA: USEPA Environmental Research Laboratory, Office of Research and Development. EPA/600/3-88/001a.

HUD (U.S. Department of Housing and Urban Development). 2003. The Practice of Low Impact Development. Washington, DC: Office of Policy Development and Research. Report prepared by NAHB Research Center, Inc. Contract No. $\mathrm{H}-21314 \mathrm{CA}$.

Hunt, W. F. and W. G. Lord. 2006. Bioretention Performance, Design, Construction and Maintenance. Raleigh, NC: North Carolina State University. Urban Waterways, N.C. Cooperative Extension publication no. AGW-588-05.

James, W., L. E. Rossman and W. R. James. 2010. User's Guide To SWMM5, 13th edn. Guelph: CHI Press.

Lee, J. G., and J. P. Heaney. 2003. “Estimation of Urban Imperviousness and its Impacts on Storm Water Systems." Journal of Water Resources Planning and Management 129 (5): 419-26.

Leopold, L. B. 1968. Hydrology for Urban Planning: A Guidebook on the Hydrologic Effects of Urban Land Use. Washington, DC: U.S. Geological Survey. Circular 554.

Lim, K. J., B. A. Engel, Z. Tang, J. Choi, K. Kim, S. Muthukrishnan and D. Tripathy. 2005. "Automated Web GIS-Based Hydrograph Analysis Tool, WHAT." JAWRA Journal of the American Water Resources Association (6): 1407-16.

Lloyd, S. D. 2001. "Water Sensitive Urban Design in the Australian Context." Synthesis of a conference held 30-31 August 2000, Melbourne, Australia.
Moriasi, D. N., J. G. Arnold, M. W. Liew, R. L. Bingner, R. D. Harmel and T. L. Veith. 2007. "Model Evaluation Guidelines for Systematic Quantification of Accuracy in Watershed Simulations." Soil \& Water Division of ASABE 50 (3): 885-900.

MWS (Metro Water Services). 2012. Stormwater Management Manual, Volume 5: Low Impact Development. Nashville, TN: Metropolitan Government of Nashville and Davidson County.

http://www.nashville.gov/portals/0/SiteContent/WaterServices/Stormwater/docs/SWMM/vol5/SWMM_Vol5LIDManual_2012.pdf.

NRCS (Natural Resources Conservation Service). 2014. Web Soil Survey. http://websoilsurvey.nrcs.usda.gov/app/.

O'Driscoll, M., S. Clinton, A. Jefferson, A. Manda and S. McMillan. 2010. “Urbanization Effects on Watershed Hydrology and In-Stream Processes in the Southern United States." Water 2 (3): 605-48.

PGC (Prince George's County). 1999a. Low Impact Development Design Strategies: An Integrated Design Approach. Prince George County, MD: Department of Environmental Resources. http://water.epa.gov/polwaste/green/upload/lidnatl.pdf.

PGC (Prince George's County). 1999b. Low Impact Development Hydrologic Analysis. Prince George's County, MD: Department of Environmental Resources. http://www.epa.gov/owow/nps/lid/lid_hydr.pdf.

Rose, S. and N. E. Peters. 2001. "Effects of Urbanization on Streamflow in the Atlanta Area (Georgia, USA): A Comparative Hydrological Approach." Hydrological Processes 15:1441-57.

Rossman, L. 2010. Storm Water Management Model User's Manual (Version 5). Cincinnati, OH: USEPA National Risk Management Research Laboratory. EPA/600/R-05/040.

Rowe, D. B. 2011. “Green Roofs as a Means of Pollution Abatement." Environmental Pollution 159:2100-10.

Roy, A. H. and W. D. Shuster. 2009. "Assessing Impervious Surface Connectivity and Applications for Watershed Management." JAWRA Journal of the American Water Resources Association 45 (1): 198-209.

Roy-Poirier, A., P. Champagne and Y. Filion. 2010. “Review of Bioretention System Research and Design: Past, Present and Future." Journal of Environmental Engineering 136 (9): 878-89.

Scholz, M. and P. Grabowiecki. 2007. "Review of Permeable Pavement Systems." Building and Environment 42:3830-6.

Shuster, W. D., J. Bonta, H.Thurston, E. Warnemunde and D. R. Smith. 2005. “Impacts of Impervious Surface on Watershed Hydrology: A Review." Urban Water Journal 2(4): 263-75.

Sutherland, R. C. 2000. "Methods for Estimating Effective Impervious Cover." Article 32 in The Practice of Watershed Protection. Ellicott City, MD: Center for Watershed Protection.

Tang, Z., B. A. Engel, B. C. Pijanowski and K. J. Lim. 2005. “Forecasting Land Use Change and its Environmental Impact at a 
Watershed Scale." Journal of Environmental Management 76:35-45.

USEPA (U.S. Environmental Protection Agency). 2000. Low Impact Development (LID): A Literature Review. Washington, DC: USEPA Office of Water. EPA-841-B-00-005.

USGS and NRCS (United States Geological Survey and Natural Resouce Conservation Service). 2012. Federal Standards and Procedures for the National Watershed Boundary Dataset (WBD), 3rd edn. Reston, VA: U.S. Geological Survey and U.S. Department of Agriculture, Natural Resources Conservation Service.

Walsh, T. C., C. A. Pomeroy and S. J. Burian. 2013. “Hydrologic Modeling Analysis of a Passive Residential Rainwater Harvesting Program in an Urbanized Semi-Arid Watershed." Journal of Hydrology 508:240-53.
WDNR (Wisconsin Department of Natural Resources). 2003. Rain Gardens: A How-to Manual for Homeowners. Madison, WI: Wisconsin Department of Natural Resources.

WVDEP (West Virginia Department of Environmental Protection). 2012. West Virginia Stormwater Management and Design Guidance Manual. Charleston, WV: West Virgina Department of Environmental Protection.

Zimmer, C. A., I. W. Heathcote, H. R. Whiteley and H. Schroeter. 2007. “Low Impact Development Practices for Stormwater: Implications for Urban Hydrology." Canadian Water Resources Journal 32(3): 193-212. 